\title{
Subaltern jugun ianfu dalam cerpen Kapotjes dan Batu yang Terapung karya Faisal Oddang: Tinjauan poskolonial Gayatri Spivak
}

\section{Iswadi Bahardur}

Program Studi Pendidikan Bahasa dan Sastra Indonesia, STKIP PGRI Sumatera Barat, Jl. Gunung Pangilun, Kecamatan Padang Utara, Kota Padang, Padang, Indonesia

iswadi@stkip-pgri-sumbar.ac.id

"Corresponding author: iswadi@stkip-pgri-sumbar.ac.id

\begin{tabular}{|c|c|c|}
\hline Sejarah Artikel & Diterima: 9 September 2020 & Tersedia Daring: 30 Oktober 2020 \\
\hline \multicolumn{3}{|c|}{ ABSTRAK } \\
\hline $\begin{array}{l}\text { Eksploitasi seksu } \\
\text { yang direpresenta } \\
\text { belakang tersebut } \\
\text { subaltern karena } \\
\text { cerpen karya Fai } \\
\text { kalimat-kalimat c } \\
\text { subaltern jugun } 1 \\
\text { pribumi subalter } \\
\text { ianfu bernama Su } \\
\text { dominasi superio } \\
\text { diterapkan adal } \\
\text { subalternisasi terl } \\
\text { yang diwujudkan } \\
\text { (5) paksaan men } \\
\text { ianfu. Dominasi }\end{array}$ & $\begin{array}{l}\text { dan kekerasan fisik yang dilakukan tentara Jepang terhadap peremp } \\
\text { kan kembali dalam teks-teks sastra pasca-kolonial, menjadi satu hal } \\
\text { tujuan penelitian ini adalah menganalisis dan mengungkapkan per } \\
\text { paksa oleh tentara Jepang menjadi jugun ianfu. Sumber data untul } \\
\text { I Oddang berjudul Kapotjes dan Batu yang Terapung. Data dala } \\
\text { lam bentuk narasi dalam sudut pandang pengarang, maupun dialog } \\
\text { fu. Metode penelitian kualitatif dan pendekatan analisis isi diguna } \\
\text { ang menjadi jugun ianfudalam cerpen Kapotjes dan batu yang Ter. } \\
\text { ani atau Hana. Telaah terhadap penokohan Suriani meliputi gamba } \\
\text { tokoh lain terhadap Suriani yang tergambar dalam teks dialog da } \\
\text { metode analisis hermeneutika, sesuai dengan pandangan } \\
\text { dap jugun ianfu dalam cerpen Kapotjes dan Batu yang Terapung } \\
\text { alam (I) tindakan pelecehan fisik, (2) perkosaan, (3) eksploitasi da } \\
\text { ormati lagu kebangsaan Jepang, serta (6) penghilangan hak-hak ke } \\
\text { sebut berdampak pada kerusakan fisik serta trauma psikis yang ber }\end{array}$ & $\begin{array}{l}\text { n pribumi di era penjajahan tahun I942-I945 } \\
\text { ng menarik untuk dikaji. Relevan dengan latar } \\
\text { asalahan perempuan pribumi yang mengalami } \\
\text { nengungkapkan permasalahan tersebut adalah } \\
\text { penelitian ini adalah satuan kata, frasa, serta } \\
\text { itartokoh yang menggambarkan permasalahan } \\
\text { n untuk mengungkapkan masalah perempuan } \\
\text { ung dilakukan melalui telaah penokohan jugun } \\
\text { n fisik, psikis, tindakan, kepribadian, dan relasi } \\
\text { monolog cerpen. Tahapan analisis isi yang } \\
\text { rippendoff. Hasil penelitian menunjukkan } \\
\text { adi karena dominasi kekuasaan tentara Jepang } \\
\text { serdagangan seksual, (4) penggantian identitas, } \\
\text { basan perempuan yang dipaksa menjadi jugun } \\
\text { uara pada upaya perlawanan. }\end{array}$ \\
\hline
\end{tabular}

\section{Kata Kunci Hegemoni, Jugun ianfu, Poskolonial, Spivak, Subaltern}

The sexual exploitation and physical violence committed by Japanese soldiers against indigenous women in the colonial era in 1942-1945, which is represented in post-colonial literary texts, is an interesting thing to study. Relevant to this background, the purpose of this study is to analyze and reveal the problems of indigenous women who experience subalterns because Japanese soldiers force them to become jugun ianfu. The data source to reveal this problem is a short story by Faisal Oddang entitled Kapotjes and Batu yang Terapung. The data in this study are units of words, phrases, and sentences in the form of narration from the author's point of view and dialogue between characters that describes the subaltern problems of jugun ianfu. Qualitative research methods and content analysis approaches are used to reveal the problem of native subaltern women who become jugun ianfu in the short stories of Kapotjes and Batu yang Terapung, which are carried out through the analysis of the characterization of jugun ianfu named Suriani or Hana. Suriani's characterization analysis includes physical, psychological, action, personality, and superior domination relations of other figures towards Suriani, which are depicted in the dialogue text and short story monologue. The content analysis stage applied is the hermeneutic analysis method in accordance with Krippendoff's view. The results showed that the subalternization of jugun ianfu in the short stories of Kapotjes and Batu yang Terapung occurred due to the domination of Japanese military power, which was manifested in (I) acts of physical abuse, (2) rape, (3) sexual exploitation and trafficking, (4) identity replacement, (5) compulsion to respect the Japanese national anthem, and (6) deprivation of women's freedom rights who are forced to become jugun ianfu. This domination has an impact on physical damage and psychological trauma that leads to resistance efforts.

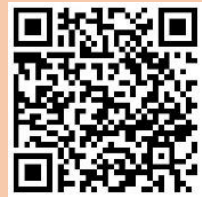

Copyright@2020, Iswadi Bahardur This is an open access article under the $\mathrm{CC}-\mathrm{BY}-3.0$ license

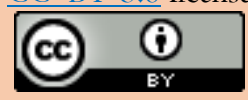

\begin{tabular}{ll}
\hline \hline Keywords & Hegemony, Jugun ianfu, Postcolonial, Spivak, Subaltern \\
\hline \hline How to Cite & Bahardur, I. (2020). Subaltern jugun ianfu dalam cerpen Kapotjes dan Batu yang Terapung karya Faisal \\
& Oddang: Tinjauan poskolonial Gayatri Spivak. KEMBARA: Jurnal Keilmuan Bahasa, Sastra, dan \\
& Pengajarannya (e-Journal), 6(2). I88-204. doi: https://doi.org/I0.22219/kembara.v6i2.I3545 \\
\hline \hline
\end{tabular}




\section{PENDAHULUAN}

Studi ilmiah sastra Indonesia terkait masalah jugun ianfu sampai saat ini masih belum mendapat banyak perhatian. Hal itu terbukti dengan minimnya hasil kajian jugun ianfu yang dipublikasikan secara ilmiah. Berdasarkan penelusuran literatur yang peneliti lakukan, sampai saat ini hanya terdapat dua publikasi penelitian masalah jugun ianfu dalam novel karya pengarang Indonesia. Hasil penelitian pertama yang mengaji masalah dimensi pernyaian dan jugun ianfu dalam novel Mirah dari Banda karya Hanna Rambe dengan perspektif feminisme eksitensinsialis (Pramana et al., 2013). Penelitian kedua tentang representasi penindasan ganda dalam novel Mirah dari Banda karya Hanna Rambe berdasarkan perspektif feminisme poskolonial (Ilma, 2016). Selain keterbatasan jumlah, kedua hasil penelitian tersebut juga belum berhasil mengeksplorasi gambaran ruang lingkup penyebab, dampak, serta respon perempuan Indonesia yang menjadi jugun ianfu dalam novel yang diteliti. Di luar kedua hasil penelitian tersebut, sejarah jugun ianfu di Indonesia justru menunjukkan fakta yang lebih kompleks. Praktik jugun ianfu dilakukan oleh Jepang terhadap perempuan Indonesia dalam kurun waktu penjajahannya mulai tahun 1942-I945. Hal itu sejalan dengan tindakan penjajahan Jepang di negara Asia Tenggara lain, seperti China, Filipina, Korea Selatan, dan Malaysia di masa Perang Dunia ke-2. Pascakemerdekaan Indonesia, fakta tentang jugun ianfu tidak lagi diperbincangkan, baik secara ilmiah, maupun populer (Savitri, 2010). Menurut catatan hasil penelitian di bidang sejarah Kristi (2016) kasus jugun ianfu di Indonesia mulai terdata tahun 2007 sebanyak II66 orang, khusus di daerah Yogyakarta. Menurut penelitian tersebut, sikap pemerintah dan masyarakat Indonesia menanggapi fakta yang mulai terkuak di tahun 1993 itu dinilai pasif, jika dibandingkan dengan negara lain, seperti Korea Selatan. Catatan terbaru hasil temuan aktivis Indonesia, Ekahindra, terdapat 200.000 perempuan yang menjadi jugun ianfu selama Perang Asia Timur Raya tahun I93I-I945 di seluruh negara Asia (Geographic, 2020). Hasil penelitian lainnya McGregor (2016) menyatakan bahwa sikap pasif Indonesia terhadap nasib para jugun ianfu dipicu oleh berbagai faktor. Faktor tersebut di antaranya adalah pemikiran tentang etika moral serta penolakan banyak pihak terhadap dukungan penyelesaian kasus jugun ianfu di Indonesia. Perempuan yang pernah menjadi jugun ianfu berasal dari keluarga yang menganut budaya timur, sehingga upayanya membuka fakta sejarah terkendala oleh gagasan kolektif tentang aib, rasa malu, dan etika budaya ketimuran. Faktor lainnya adalah keterbatasan dukungan yang diberikan oleh pemerintah Indonesia terhadap perempuan korban jugun ianfu, karena alasan bahwa permasalahan jugun ianfu adalah aib nasional.

Dikaji dari segi istilah, jugun ianfu atau comfort women adalah perempuan-perempuan pribumi yang berprofesi sebagai penghibur militer atau perempuan pekerja seks untuk tentara Jepang era Perang Asia Timur Raya. Sebagai bagian dari rakyat jajahan Jepang, perempuan jugun ianfu dimobilisasi dengan tugas mencuci pakaian tentara, membersihkan barak, dan beberapa pekerjaan berat seperti membawa amunisi. Pada malam hari jugun ianfu bertugas sebagai pelayan seksual tentara Jepang. Jugun ianfu yang menolak memberikan layanan seksual akan dihukum dengan cara ditarik rambutnya dan diseret setengah telanjang (Nozaki, 2005). Hal itu sesuai dengan ketentuan yang ditetapkan tentara Jepang, bahwa perempuan jugun ianfu harus tunduk dalam hegemoni kultur sebagai pekerja seks untuk militer Jepang.

Hegemoni kekuasaan tentara Jepang terhadap perempuan subaltern jugun ianfu menimbulkan dampak secara fisik dan psikis. Dampak tersebut melekat secara permanen karena tentara Jepang memposisikan jugun ianfu sebagai subjek yang dimarginalkan, tersubordnasi, serta dianggap tidak memiliki suara. Dalam hasil penelitian tentang jugun ianfu yang telah dilakukan oleh Hein (2016) dinyatakan dampak yang dialami jugun ianfu secara moral terus berlanjut, meski pemerintah Jepang pada tahun 1993 telah membuat rekonsiliasi untuk permintaan maaf. Rekonsiliasi itu ternyata tidak berhasil karena stereotip perempuan penghibur yang melekat pada jugun ianfu telah meninggalkan tekanan psikologis yang berkelanjutan.

Dalam konteks sejarah kolonial di Indonesia dan Asia, jugun ianfu dapat dipandang sebagai perwujudan kelompok subaltern. Pandangan tersebut sesuai dengan teori yang dikemukakan oleh Gramsci. Konsep tentang subaltern pertama kali dikemukakan oleh Antonio Gramsci dalam artikelnya Notes on Italian History (Mussi, 2017; Bharati \& Adkoli, 2018). Menurut konsep Gramsci, kelas subaltern adalah

Iswadi Bahardur, Subaltern jugun ianfu dalam cerpen Kapotjes dan Batu yang Terapung karya Faisal Oddang: Tinjauan poskolonial Gayatri Spivak 
orang-orang yang masuk ke dalam kategori kelompok masyarakat kelas rendah yang mengalami penderitaan akibat dominasi hegemoni kelompok masyarakat penguasa atau penjajah (Kumar, 2016). Subalternitas tercipta karena penghapusan hak-hak masyarakat terjajah, meski faktanya adalah individu yang memiliki kontribusi dalam sejarah dan kebudayaan bangsa asalnya. Gramsci juga berpendapat bahwa kelompok subaltern tercipta karena kelahiran partai-partai baru dan kelompok-kelompok dominan yang bertujuan menghancurkan tatanan masyarakat pribumi (El, 20I2). Pandangan Gramsci tersebut memperkuat alasan perempuan jugun ianfu adalah bagian dari kelompk perempuan subaltern. Hal itu diperkuat oleh temuan penelitian keberadaan perempuan jugun ianfu, khususnya di daerah Jawa Barat. Dalam penelitian tersebut dinyatakan bahwa subalternisasi terhadap jugun ianfu di daerah Jawa Barat terjadi karena tindakan tentara Jepang mereduksi tubuh perempuan pribumi sebagai objek kekerasan, seksual, dan marginalisasi. Tindakan itu dialami oleh jugun ianfu yang berasal dari kota Cimahi, Sukabumi, Bogor, dan Sumedang (Rahma, Suswandari \& Naredi, 2020).

Istilah subaltern itu berasal dari bahasa Latin subaltern us. Dalam bahasa Latin sub berarti under dan alter yang dapat diartikan sebagai sesuatu lainnya. Secara harfiah arti suku kata tersebut telah menjelaskan makna orang atau kelompok yang lebih rendah (Setiawan, 2018). Oleh banyak pemikir, istilah tersebut disinonimkan dengan istilah proletariat yang juga merujuk pada arti orang atau kelompok orang dengan status dan posisi yang lebih rendah, baik karena ras, kelas, jenis kelamin, etnis atau agama (Dharmaraj, 20I4). Gagasan awal tentang subaltern yang dikemukakan oleh Gramsci memang tidak langsung merujuk kepada jugun ianfu, tetapi substansi pemikiran tersebut relevan dengan pengertian jugun ianfu sebagai kelompok tertindas oleh hegemoni budaya penjajahan Jepang. Tokoh-tokoh selain Gramsci yang berperan penting dalam kajian jugun ianfu ialah Yuki Tanaka (Tanaka, 2002) dan Ikuhito Hata (Hata, 2018), sedangkan kajian subaltern diantaranya adalah oleh Guha (Guha \& Spivak, 2002), Spivak (Chaturvedi, 2000; Spivak, Landry, \& MacLean, 1996; Young, 2003).

Masalah subaltern semakin dimimnati sejak dikritisi kembali dalam esai Gayatri Spivak yang berjudul Can the Subaltern Speak? (Williams, Williams, \& Chrisman, 20II). Dalam essay tersebut Spivak mempertanyakan posisi dan suara perempuan korban penjajahan kolonial, khususnya di India. Menurut Spivak, subaltern adalah kelompok yang terpinggirkan, subjek yang dieksploitasi sebagai hak milik pihak pengeksploitasi yaitu pihak Barat (Mashaqi, 2017). Kelompok pengeksploitasi subaltern yang disebut Spivak sebagai kelompok intelektual tidak pernah memposisikan kekuatan dan keinginan apapun yang berasal dari subjek "Yang Lain" (Yousef \& Al-Rubwfiq, 2016). Spivak juga berpendapat bahwa perempuan subaltern adalah posisi tanpa identitas, subjek tanpa status, sosok yang disita suaranya, terputus akses mobilitasnya ke pusat kekuasaan yang dominan. Perempuan subaltern adalah suara-suara yang didominasi oleh kelompok hegemonik yang berdampak terhadap kehancuran fisik dan psikisnya (De Jong \& Mascat, 2016). Pemikiran Spivak tersebut misalnya, secara langsung diadopsi oleh peneliti di India untuk membongkar praktik subalternitas Inggris terhadap masyarakat di Bengali. Penelitian Sengupta terhadap karya fiksi berjudul A Journal of Forty-Eight Hours of the Year 1945 karya Kylas Chunder Dutt menunjukkan perjuangan kelompok subaltern di Kota Bengali India untuk representasikan diri di tengah ancaman kolonial Inggris. Sengupta menyimpulkan teks fiksi karya Kylas Chunder Dutt adalah perwakilan suara subaltern di India terhadap penindasan yang menimbulkan multikonflik, serta representasi dari negosiasi budaya asli Bengali dengan Inggris, sekaligus upaya pembentukan kesadaran pribumi yang telah disubalternisasi oleh kolonial (Sengupta, 2017).

Dalam konteks teori poskolonial, subaltern juga berkaitan dengan marginalisasi perempuan karena warna kulit. Bagi bangsa penjajah, deskripsi warna kulit apapun kehilangan arti persuasif. Stratifikasi yang diperlukan dari subjek-konstitusi kolonial dalam fase pertama imperialisme kapitalis menyebabkan warna kulit atau suku bangsa tidak akan mempengaruhi akses perempuan ke ruang emansipasi (Ardianto, 2020). Itu sebabnya menurut Spivak, dalam konteks Barat, negara Timur adalah objek dan Barat adalah subjek yang berkedaulatan dalam pengetahuan. Perempuan-perempuan di negara kolonial adalah bayangan yang tidak memiliki identitas, jika dibandingkan dengan laki-laki. Spivak memandang bahwa Timur bagi Barat adalah subjek di dunia ketiga. Sebagai subjek dunia ketiga, Timur diposisikan sebagai subjek yang mengalami dominasi dan ketidakadilan dari subjek 
pertama. Subjek dunia ketiga tersebut adalah suara-suara yang terindas, diantaranya kaum perempuan (Sumra, 2018).

Berpedoman pada pemikiran Spivak, perempuan subaltern, termasuk jugun ianfu di masa penjajahan Jepang adalah bagian dari perempuan Asia atau non-Eropa yang berada dalam penindasan. Perempuanperempuan tersebut berupaya menyelamatkan diri dengan membangun kesadaran atas hak-haknya dengan ucapan praktis sendiri. Pandangan itu sejalan dengan pendapat ahli lain, (Ashcroft, Bill, 2007) erotika visi kolonial memandang negara jajahan diumpamakan sebagai tubuh perempuan yang menggiurkan dan pantas untuk ditaklukkan secara seksual. Bertolak dari pandangan Spivak dan ahli lain tersebut, dapat dipetakan kajian subaltern terkait erat dengan kolonial, masyarakat kelas bawah atau masyarakat marginal di berbagai negara bekas jajahan kolonial, dominasi serta pengaruh kolonial terhadap eksistensi fisik dan psikis masyarakat marginal, dan upaya masyarakat tersebut untuk melakukan perlawanan (Brennan \& Guha, 1982). Seturut dengan hal itu, tujuan penelitian ini mencakup analisis permasalahan dominasi penjajahan Jepang terhadap subaltern jugun ianfu, dampak yang diterima jugun ianfu secara fisik dan psikis, serta upaya resistensinya.

Karya sastra yang ditulis oleh pengarang Indonesia, baik era kolonial, maupun pascakolonial telah mempresentasikan beragam permasalahan masyarakat Indonesia. Masalah tersebut antara lain kesenjangan sosial karena kolonialisme (Farida \& Andalas, 2019), penindasan, serta romantika percintaan dalam konstelasi budaya penjajah (Susanto \& Wati, 2019; Setiawan, 2019) mimikri, ambivalensi, serta resistensi pribumi terhadap penjajahan Jepang (Ningrum, Waluyo, \& Winarni, 2017). Diantara karya sastra yang mempresentasikan permasalahan tersebut adalah trilogi Bumi Manusia dan Perburuan(Pramoedya Ananta Toer), Mirah Dari Banda (Hanna Rambe), Jugun Ianfu: Jangan Panggil Aku Miyako (E. Rokajat Asura), Gadis Pantai (Pramoedya Ananta Toer), serta cerpen-cerpen dari pengarang angkatan mutakhir. Satu cerpen dari pengarang mutakhir yang mengambil tema perempuan jugun ianfu adalah Kapotjes dan Batu yang Terapung yang terhimpun dalam kumpulan cerita pendek Sawerigading Datang Dari Laut karya Faisal Oddang (Oddang, 2019).

Cerita pendek Kapotjes dan Batu yang Terapung adalah karya sastra dari sastrawan muda Indonesia yang sarat dengan muatan persoalan yang kontekstual untuk dibicarakan secara ilmiah. Oleh karena itu, ada beberapa alasan yang melatarbelakangi pemilihan cerpen Kapotjes dan Batu yang Terapung karya Faisal Oddang sebagai sumber data penelitian. Secara kualitas karya, cerpen ini sangat terjaga karena telah dipublikasikan di surat kabar harian Kompas edisi 3 Juni 2018. Setelah diterbitkan oleh Kompas, cerpen Kapotjes dan Batu yang Terapung dihimpun dan diterbitkan kembali menjadi buku kumpulan cerita pendek Faisal Oddang oleh penerbit DIVA Press pada tahun 2019 dengan judul Sawerigading Datang dari Laut. Pada tahun 2020 Sawerigading Datang dari Laut juga dipilih sebagai nominator penghargaan Buku Sastra Terbaik dari Badan Pengembangan dan Pembinaan Bahasa. Selain prestasi tersebut, Faisal Oddang adalah sastrawan nasional yang mumpuni karena pernah mendapat penghargaan ASEAN Young Writers Award 2014 dari pemerintah Thailand, Penulis Cerpen Terbaik Kompas 20I5, Tokoh Seni Tempo 2015, nominator penghargaan Kusala Sastra Khatulistiwa 2018, serta pemenang sayembara novel Dewan Kesenian Jakara 2014.

Ditinjau dari segi latar, struktur cerita serta penokohan, cerpen Kapotjes dan Batu yang Terapung juga sangat penting untuk diteliti karena relevan dengan sejarah kehidupan jugun ianfu di Indonesia era penjajahan Jepang. Cerpen ini mengambil latar penceritaan Kota Sengkang dan Makassar di Provinsi Sulawesi semasa dijajah oleh tentara Jepang. Subaltern jugun ianfu direfleksikan melalui dua orang tokoh perempuan bernama Hana dan Kazumi yang lahir di Sengkang, tetapi dilarikan tentara Jepang ke Makassar untuk dijadikan jugun ianfu. Dialog dan narasi tokoh Hana mewakili semua bentuk dominasi tentara Jepang terhadap jugun ianfu, pengaruhnya terhadap fisik dan psikis, serta respon perlawanan atau wacana tandingan yang disuarakan terhadap wacana hegemonik tentara Jepang. Pada diri tokoh Hana dapat ditelusuri potret pemberontakan perempuan pribumi terhadap dominasi penjajah yang mengeksploitasi tubuh dan jiwa perempuan pribumi untuk kepentingan politik dan kebutuhan seksual. Meskipun perlawanan yang dilakukan oleh Hana tidak menghasilkan kemenangan, namun secara tersirat telah menggambarkan kehidupan marginal perempuan pribumi di Sulawesi Selatan masa penjajahan Jepang serta gerakan perlawanannya yang sejalan dengan pemikiran sublatern studies di dunia ketiga. Upaya perlawanan Hana dengan cara melarikan diri sejalan dengan strategi perlawanan politis kelompok subaltern terhadap hiraki kelas sosial, marginalisasi, serta subordinasi yang dilakukan kolonial (Chandra,

Iswadi Bahardur, Subaltern jugun ianfu dalam cerpen Kapotjes dan Batu yang Terapung karya Faisal Oddang: Tinjauan poskolonial Gayatri Spivak 
20I5). Selaras dengan pemikiran gerakan subaltern studies dan refleksinya dalam cerpen karya Faisal Oddang tersebut, maka penelitian ini juga bertujuan menganalisis dan menafsirkan kembali masalah (a) bentukbentuk dominasi ideologi tentara Jepang terhadap subaltern jugun ianfur, (b) pengaruh dominasi kekuasaan tentara Jepang terhadap fisik dan psikis subaltern jugun ianfur, serta (c) upaya perlawanan yang dilakukan tokoh Hana sebagai wujud perlawanan subaltern jugun ianfu terhadap dominasi kekuasaan tentara Jepang.

Ada beberapa penelitian terdahulu terkait dengan kajian jugun ianfu dan subaltern yang telah dilakukan oleh peneliti lain. Penelitian tentang jugun ianfu dalam novel Indonesia berlatar penjajahan Jepang, seperti telah dijelaskan di bagian awal tulisan ini, dilakukan oleh Ilma (2016), dan Pramana, Sri Suwarni Rahayu \& Sri Mariat (2013). Selanjutnya penelitian tentang subalttern dalam kajian lebih luas dan termasuk karya sastra di luar Indonesia dilakukan oleh Yu (2013), Santosa \& Ocktarani (2020), Tami, Faruk \& Adi (2017). Pramana et al., (2013) meneliti permasalahan jugun ianfu dan pernyaian atau pergundikan dalam novel Mirah dari Banda karya Hana Rambe menggunakan teori feminisme eksistensialisme. Tujuannya adalah mendeskripsikan keterkaitan antarunsur feminisme eksistensialis dan ketidakadilan gender yang diungkapkan dalam novel karya Hanna Rambe. Hasil penelitiannya mengungkapkan dua permasalahan utama, yaitu Mirah sebagai representasi perempuan kelas bawah, tertindas, dan miskin. Permasalahan kedua adalah perjuangan Mirah untuk menaikan derajat dan mendapatkan kebebasan, salah satu caranya adalah dengan memasuki kehidupan pergundikan. Secara spesifik hasil temuan Pramana tidak mengungkapkan secara detail kaitan kajian feminisme eksitensialisme dengan temuan jugun ianfu. Dengan demikian dapat disimpulkan temuan penelitian tersebut belum menjawab permasalahan substansi tentang jugun ianfu dalam pandangan feminis. Secara teoretis dan ruang lingkup permasalahan yang dikaji, penelitian Pramana berbeda dengan penelitian terhadap cerita pendek Kapotjes dan Batu yang Terapung karya Faisal Oddang. Persamaan hanya bersifat umum, yaitu sama-sama menyangkut permasalahan perempuan.

Penelitian Ilma (2016) menggunakan kajian feminisme poskolonial untuk mengungkapkan bentuk penindasan ganda yang dialami oleh tokoh perempuan sebagai dampak dari kolonialisme dan hegemoni maskulin patriarki. Dalam hasil penelitiannya, Ilma menjelaskan bahwa bentuk penindasan ganda tersebut meliputi pekerjaan sebagai babu, pelayan Nyai, serta buruh kebun. Sebagai babu, Mirah memiliki kewajiban untuk mengurus urusan rumah tangga, mengurus tuannya, bertanggung jawab dalam pekerjaan dapur, sumur, dan kebutuhan sekolah anak-anak Nyonya Besar. Sebagai kuli, Mirah juga dituntut untuk bekerja keras di perkebunan dan tidak boleh melakukan kesalahan dalam memetik buah pala. Penelitian Ilma tersebut juga berbeda secara teori dan aspek kajian dengan penelitian terhadap cerpen Kapotjes dan Batu yang Terapung karya Faisal Oddang. Ilma hanya mengkaji masalah perempuan dari segi dua bentuk penindasan di zaman kolonial dilihat dari sudut pandang feminisme, sedangkan penelitian ini menerapkan kajian poskolonial subaltern Gayatri Spivak.

Yu (2013) mengkaji masalah subaltern dalam dua film Filipina berjudul All Under the Moon karya Yangil Choi dan Wandeugi karya sutradara Han Lee dengan pendekatan teori subaltern serta poskolonial Spivak dan Babha. Hasil penelitian Yu secara spesifik membongkar fakta subaltern dalam masyarakat Filipina dan Korea yang memperlihatkan perbedaan strata sosial sangat tajam. Perempuan Korea justru memilih menjadi subaltern murni dengan menggunakan cara mimikri, ambivalensi, serta hibriditas untuk menyembunyikan identitas aslinya dari serangan kapitalis kolonial. Paparan hasil penelitian Yu memperlihatkan perbedaan dengan substansi penelitian subaltern jugun ianfu dalam cerpen Kapotjes dan Batu yang Terapung karya Faisal Oddang. Latar belakang kultur dan kondisi sosial masyarakat di negara Filipina dan Korea yang berbeda dengan Indonesia memperlihatkan fakta bahwa perempuan Indonesia di Makassar yang dipaksa oleh tentara Jepang menjadi jugun ianfu mengalami penindasan dan marginalisasi yang lebih berat.

Temuan penelitian Yu juga dapat dibandingkan dengan temuan penelitian Tami, Faruk, \& Adi, (2017) yang mengkaji hegemoni budaya dan subaltern dalam novel religi populer berjudul Ketika Mas Gagah Pergi karya Helvy Tiana Rosa. Tami menggunakan pendekatan teori hegemoni Antoni Gramsci untuk menganalisis praktik hegemoni dua budaya yang saling bertentangan, yaitu budaya Islam dan budaya liberal yang melahirkan kelompok hegemonik dan subaltern. Pertemuan kelompok hegemonik budaya Islam tradisional yang menolak modernitas dengan kelompok modernitas yang mempraktikkan 
Islam hanya untuk kepentingan domain pribadi akhirnya memunculkan negosiasi dan kompromi antara kelompok hegemoni serta kelompok subaltern. Perempuan dan lelaki muslim era modern yang diwakili oleh tokoh Gita dan Mas Gagah menghadapi hegemoni budaya bukan dengan cara melebur menjadi subaltern murni. Sebaliknya, kedua tokoh tersebut berusaha melakukan negosiasi dan kompromi untuk sebuah nilai baru yang tidak bertentangan. Temuan ini memperlihatkan hal kontras dengan sikap perempuan Korea dan Filipina dalam menyikapi hegemoni neokolonial seperti yang telah diungkapkan dalam temuan penelitian (Yu, 2013).

Santosa \& Ocktarani (2020) mengkaji dekonstruksi narasi subaltern dalam naskah drama Nyai Ahmad Dahlan karya Dyah Kalsitorini menggunakan pendekatan teori subaltern Spivak dan dekonstruksi. Permasalahan tersebut dikerucutkan menjadi dua aspek kajian, yaitu kontestasi subalternitas perempuan Jawa Islam dan bentuk dekonstruksi narasi tokoh Siti Walidah dalam naskah drama Nyai Ahmad Dahlan. Hasil penelitian ini mengungkapkan konstruksi sosok perempuan Jawa Islam yang penuh kasih sayang, lembut, dan mengabdi pada suami, diubah oleh Nyai Ahamd Dahlan dengan keterlibatannya di organisasi Islam. Akan tetapi, uraian analisis penelitian ini tidak memperlihatkan keterkaitan yang kuat antara cara kerja metode dekonstruksi dengan teori subaltern, sehingga argumentasi peneliti lebih cenderung sebagai hasil analisis dari segi sosiologis. Dibandingkan dengan penelitian masalah subaltern jugun ianfu dalam cerpen Kapotjes dan Batu yang Terapung karya Faisal Oddang, penelitian Santosa memiliki kesamaan yaitu, teori subaltern Spivak, tetapi berbeda dari segi aspek kajian.

Saxena (2019) mengkaji masalah jejak trauma Perang Dunia dan kolonial terhadap masyarakat pascakolonial di Malaysia dalam novel karya Tan Twan Eng berjudul The Gift of Rain. Hasil penelitian ini mengungkapkan rekam jejak penjajahan kolonial dan Perang Dunia ke-2 terhadap masyarakat di Malaysia meninggalkan trauma berkelanjutan, walaupun telah memasuki masa pascakolonial. Trauma tersebut mewujud dalam pilihan sikap hibriditas untuk menyembuhkan trauma psikis karena kegagalan mengembalikan identitas asli. Secara detail hasil penelitian ini tidak mengungkapkan tentang kajian subaltern, meskipun permasalahan penelitiannya identik dengan kelompok masyarakat subaltern. Berdasarkan perbandingan terhadap persamaan dan perbedaan substansi masing-masing penelitian tersebut dapat dikemukakan kelebihan penelitian masalah subaltern jugun ianfu dalam cerpen Kapotjes dan Batu yang Terapung karya Faisal Oddang.

Dibandingkan penelitian yang telah ada tersebut, penelitian ini memiliki kelebihan dari segi nilai kebaruan dan inovasi pemikiran. Nilai kebaruan tersebut terletak pada konsentrasi kajian masalah jugun ianfu yang ditinjau dari perpektif teori subaltern Gayatri Spivak. Nilai kebaruan berikutnya tercermin dari fokus kajian yang diselaraskan dengan teori subaltern Gayatri Spivak. Peneliti mengelompokkan fokus kajian subaltern tersebut menjadi tiga, yaitu (a) bentuk dominasi kekuasaan tentara Jepang terhadap perempuan subaltern jugun ianfur, (b) pengaruh dominasi tentara Jepang terhadap perempuan subaltern jugun ianfu dan; (c) upaya perlawanan perempuan subaltern jugun ianfu terhadap dominasi kekuasaan tentara Jepang dalam cerpen Kapotjes dan Batu yang Terapung karya Faisal Oddang. Berpedoman pada tiga aspek kajian tersebut, maka dapat dipahami bahwa permasalahan subaltern jugun ianfu yang dinarasikan oleh Faisal dalam cerpen Kapotjes dan Batu yang Terapung menjadi menarik untuk dikaji karena relevan dengan kondisi kehidupan sosial budaya perempuan pribumi era penjajahan Jepang di Indonesia. Selain kemenarikan tersebut, kajian terhadap masalah subaltern jugun ianfu dalam cerpen karya Faisal Oddang juga dapat memperluas jaringan pemikiran intelektual di bidang kajian teori poskolonial, khususnya masalah subaltern menyangkut hakhak dan kehidupan yang layak bagi perempuan pribumi di era kemerdekaan.

\section{METODE}

Artikel ini merupakan hasil penelitian kualitatif, bertujuan untuk mensintesiskan dokumen pengamatan budaya, wawasan baru, dan perbedaan pendapat tentang kompleksitas individu atau sosial sebagai perwujudan makna manusia atau kritik terhadap tatanan sosial dari berbagai sumber, diantaranya teks tertulis berbentuk karya sastra (Saldana, 20II). Pendekatan analisis yang diterapkan adalah analisis isi (content analysis), yaitu teknik untuk analisis sistematis berbagai jenis teks yang tidak hanya membahas konten, tetapi juga tema dan ide utama

Iswadi Bahardur, Subaltern jugun ianfu dalam cerpen Kapotjes dan Batu yang Terapung karya Faisal Oddang: Tinjauan poskolonial Gayatri Spivak 
yang ditemukan dalam teks. Penerapan pendekatan analisis isi dalam penelitian kualitatif diimplementasikan dengan tiga langkah strategis, yaitu (a) penetapan desain penelitian yang bertujuan untuk memilih objek dan sumber data penelitian yang dipandang tepat; (b) pencarian data pokok atau data primer dan; (c) penetapan sumber-sumber teori yang menjadi pisau bedah kajian (Krippendorff, 2004). Berpedoman pada tiga langkah strategis tersebut, maka dalam penelitian ini pemilihan cerpen Kapotjes dan Batu yang Terapung karya Faisal Oddang sebagai sumber data yang menyajikan teks-teks tertulis terkait dengan masalah subaltern jugun ianfu telah dilakukan dengan pertimbangan studi ilmiah yang juga berelevansi dengan konteks sosial budaya masyarakat Indonesia masa penjajahan Jepang.

Data dalam penelitian ini adalah satuan kata, frasa, serta kalimat-kalimat dalam bentuk narasi dalam sudut pandang pengarang, maupun dialog antartokoh yang menggambarkan permasalahan subaltern jugun ianfu dalam cerpen Kapotjes dan Batu yang Terapung yang terhimpun dalam buku kumpulan cerpen Sawerigading Datang dari Laut karya Faisal Oddang (Oddang, 2019). Data tersebut dikumpulkan dengan langkah yang berpedoman pada teknik pengumpulan data kualitatif yang dikemukakan oleh Creswell (Creswell, 20I4), yaitu (a) membaca sumber data; (b) unitizing (mengambil data yang tepat dengan cara menandai teks; dan (c) mencatat dan menginventarisasi teks-teks apa yang relevan.

Untuk mendapatkan jawaban permasalahan subaltern jugun ianfu dalam cerpen Kapotjes dan Batu yang Terapung karya Faisal Oddang, maka tahapan analisis isi yang diterapkan adalah metode analisis hermeneutika, sesuai dengan pandangan Krippendoff (Krippendorff, 2004). Menurut Krippdendoff analisis isi dengan metode hermeneutika dilakukan dengan cara analisis bahasa teks, kemudian melangkah kepada analisis konteks, selanjutnya dipahami, ditafsirkan, dan didialogkan secara kontekstual dengan dinamika realitas historisnya. Analisis isi dengan metode hermeneutika tersebut selanjutnya diimplementasikan ke dalam langkah-langkah kerja analisis penelitian kualitatif yang dikemukakan oleh Miles \& Hubermen (Miles \& Hubermen, 1994). Langkah kerja tersebut adalah (a) reduksi data; (b) display data; dan (c) conclusion drawing atau verification.

\section{HASIL DAN PEMBAHASAN \\ HASIL}

Pada bagian hasil dan pembahasan akan diuraikan analisis data terkait permasalahan subaltern yang digambarkan dalam cerpen Kapotjes dan Batu yang Terapung karya Faisal Oddang. Hasil analisis data teks cerpen terkait penokohan Suriani sebagai jugun ianfu selanjutnya akan diinterpetasikan kembali menurut kajian teori poskolonial Gayatri Spivak (Nelson \& Grossberg, 1988) untuk melihat substansi masalah jugun ianfu sebagai bagian dari subaltern.

Untuk menemukan substansi permasalahan jugun ianfu sebagai bentuk subalternisasi perempuan pribumi di Makassar masa penjajahan Jepang, berikut ini akan dipaparkan temuan yang meliputi (a) dominasi tentara Jepang terhadap penokohan Suraini atau Hana; (b) pengaruh dominasi tentara Jepang terhadap fisik dan psikis tokoh Suriani; dan (c) perlawanan tokoh Suriani terhadap dominasi tentara Jepang.

\section{Dominasi Tentara Jepang terhadap Kehidupan Tokoh Suriani}

Masa penjajahan Jepang di Makassar banyak merekrut perempuan untuk dijadikan jugun ianfu atau budak seks tentara Jepang. Setelah dipilih secara jugun ianfu, perempuan-perempuan tersebut harus bersedia melayani tentara-tentara Jepang sebagai bentuk kepatuhan bangsa jajahan. Tidak hanya dipaksa menjadi pelayan nafsu, para jugun ianfu tersebut juga harus bersedia diganti nama dan identitasnya agar mencerminkan kultur masyarakat Jepang. Hal tersebut seperti dialami oleh tokoh perempuan bernama Suriani dan Kazumi dalam cerpen Kapotjes dan Batu yang Terapung. Setelah dipilih secara paksa untuk menjadi jugun ianfu, Suriani dibawa dan dikurung dalam rumah jugun ianfu. Identitas Suriani juga diubah agar mencerminkan identitas perempuan Jepang. Selain itu, Suriani juga diharuskan mengikuti upacara untuk menghormati lagu dan negara Jepang.

Nama saya Hana, bukan nama yang sebenarnya. Saya menyukai nama ini bukan karena lebih bagus dari Suriani, nama pemberian Ibu. Bagi saya, Suriani telah mati. Saya telah mengubur nama itu pada hari kedua saya menjadi 
jugun ianfu ketika tentara itu memberi nama Jepang untuk memudahkan saya melupakan masa lalu dan kampung asal. Mereka tidak mengerti bahwa tidak ada yang benar-benar mampu merebut ingatan dan masa lalu seseorang (Oddang, 2019: 97).

Kutipan tersebut menyatakan tindakan dominasi tentara Jepang terhadap eksistensi Suriani setelah menjadi jugun ianfu. Setelah dibawa ke tempat penampungan jugun ianfu, nama Suriani diganti menjadi Hana. Tujuan tentara Jepang mengganti nama Suriani menjadi Hana adalah untuk menghapus masa lalu Suriani sebagai perempuan pribumi dari Sengkang. Dengan nama Hana, Jepang menginginkan Suriani menjadi perempuan dengan identitas baru yang berbau Jepang dan melupakan masa lalunya.

Suriani mengalami pergolakan psikis yang luar biasa karena di satu sisi ia merasa senang telah mendapatkan identitas baru. Akan tetapi di sisi lain, Suriani tetap yakin bahwa penggantian namanya menjadi Hana tidak akan pernah mampu menghapus ingatan terhadap masa lalunya sebagai perempuan pribumi. Dalam kasus tegangan psikis tersebut nampak bahwa Hana atau Suriani merupakan sosok perempuan pribumi yang sudah dihilangkan suaranya oleh Jepang. Tentara Jepang memaksa penggantian nama Suriani menjadi Hana tanpa persetujuan perempuan tersebut terlebih dahulu. Tindakan tersebut menunjukkan bahwa sebagai perempuan pribumi yang dijajah oleh Jepang, Suriani adalah kelompok pinggiran, kelompok yang dianggap tidak memiliki suara, dan tidak memiliki identitas. Oleh karena dipandang tidak memiliki suara, terpinggir, kelas bawah, serta tidak beridentitas, maka tentara Jepang bebas melakukan dominasi terhadap kehidupan Suriani.

Sebagai jugun ianfu yang sudah disubalternisasi, Suriani sendiri dihadapkan pada ambivalensi; menyukai sekaligus menolak identitas dan jati dirinya yang baru. Di satu sisi Suriani menyukai nama pemberian Jepang karena dengan nama tersebut dia merasa dapat membunuh identitas dirinya di masa lalu. Akan tetapi Suriani juga membenci nama dan tindakan tentara Jepang kepadanya, karena ia masih tidak dapat melupakan identitas aslinya sebagai perempuan pribumi dari Sengkang Makassar.

Setelah menjadi jugun ianfu, Suriani harus menjalani kehidupan yang sangat menyiksa fisik dan psikisnya. Suriani mengalami kekerasan seksual, psikis, sekaligus kehilangan hak-hak menyangkut melangsungkan pernikahan dengan laki-laki yang dicintainya. Tubuh Suriani menjadi objek eksploitasi seksual tentara Jepang, sehingga perempuan itu merasa tidak mengenali tubuhnya sendiri. Selain dipaksa menjadi objek kebutuhan seksual tentara Jepang, Suriani jugga diharuskan mengikuti upcara penghormatan setiap pagi.

Saya selalu menangis sambil mematut tubuh saya berjam-jam setiap menjelang tidur. Tubuh yang berbulan-bulan saya rawat; saya lumuri bubuk sangrai ketan hitam yang ditumbuk dan mandi dengan air rebusan beras--persiapan pernikahan dengan Hammud. Sekarang, saya seperti tak mengenali tubuh ini setelah beberapa tentara Jepang menjemput paksa di rumah. Saya dibawa dengan mobil dari Sengkang ke Makassar. Ke sebuah tempat yang penuh kamar kecil dengan banyak perempuan dan banyak tentara yang berjaga. Tidak ada yang saya akrabi di tempat ini selain Kama dan Kazumi. Nama yang terakhir saya kenal belakangan, dia jarang di kamar nomor 8 miliknya. Dia lebih sering pulang ke rumah tentara Jepang yang menjadikannya istri simpanan. Sementara di kompleks pelacuran ini, setiap pagi kami dikumpulkan di lapangan untuk upacara; untuk mendengar lagu kebangsaan Jepang sebelum membungkuk beberapa saat ke arah negara mereka yang sialan itu (Oddang, 20219: 98).

Kutipan tersebut menyatakan eksploitasi seks dan kekerasan yang dilakukan tentara Jepang terhadap Suriani dan perempuan lain bernama Kazumi. Eksploitasi seks tersebut semata dilakukan tentara Jepang karena Suriani berada pada posisi sebagai perempuan kelas bawah. Statusnya sebagai jugun ianfu menyebabkan Suriani menjadi objek eksploitasi seksual dan harus mengikuti semua aturan yang diberlakukan oleh tentara Jepang. Suriani dibawa dari tempat tinggalnya di Sengkang dan ditempatkan di kamar bernomor 7, di samping kamar yang dihuni jugun ianfu lainnya. Di tempat itu, Hana atau Suriani harus melayani semua tentara Jepang dan lelaki yang membayarnya sebanyak 3-5 yen untuk berhubungan seksual.

Seperti diceritakan oleh Suriani dalam kutipan tersebut, dia telah menjadi jugun ianfu sejak dijemput paksa oleh tentara Jepang dari rumah orang tuanya di Sengkang. Pola tindakan yang dilakukan Jepang terhadap Suriani merupakan cermin dari stigma negatif yang telah dilekatkan oleh penjajah terhadap masyarakat jajahannya. Sebagai bagian dari masyarakat jajahan, Suriani adalah perempuan yang tidak memiliki hak untuk

Iswadi Bahardur, Subaltern jugun ianfu dalam cerpen Kapotjes dan Batu yang Terapung karya Faisal Oddang: Tinjauan poskolonial Gayatri Spivak 
menolak atau melakukan perlawanan terhadap penjajah. Hal itu disebabkan masyarakat jajahan diposisikan sebagai kelompok bawahan yang memang tidak dipandang memiliki identitas oleh penjajah. Penindasan yang dialami Suriani tidak hanya melalui dominasi tubuh, melainkan juga dalam hal kebebasan dan ideologi kebangsaan. Suriani tidak diperbolehkan keluar kamar yang diuntukkan sebagai tempat kurungannya. Interaksi Suriani hanya terjadi antara dia dengan Kama, lelaki pelayan rumah pelacuran. Setiap pagi Suriani dan jugun ianfu lainnya juga harus mengikuti upacara penghormatan dengan cara membungkuk ke arah asal negara penjajah tersebut. Perlakuan yang dialami Suriani tersebut merupakan bentuk perlakuan penjajah yang memiliki kekuasaan dominan dan superior terhadap warga pribumi yang dianggap sebagai kelompok bawah atau kelompok pinggiran. Sebagai pemilik kekuasaan dominan, tentara Jepang menunjukkan kekuasaan superiornya dengan memosisikan Suriani sesuai dengan kelasnya dan sesuai dengan kepentingan tentara Jepang.

\section{Pengaruh Dominasi Kekuasaan Tentara Jepang terhadap Fisik dan Psikis Tokoh Suriani}

Dominasi kekuasaan tentara Jepang terhadap kehidupan Suriani sebagai jugun ianfu telah mempengaruhi fisik dan psikisnya. Paksaan menjadi jugun ianfu tidak hanya berpengaruh pada hilangnya kebebasan, melainkan juga berdampak pada kesehatan dan keutuhan fisiknya. Suriani kehilangan keperawanan sebelum menikah dengan kekasihnya, Hammud, tubuhnya luka-luka dan berdarah akibat kekerasan seksual. Selain itu, psikis Suriani juga tertekan karena dipaksa harus melayani nafsu laki-laki Jepang.

Dia tampak bingung, mungkin tidak tahu dia sedang di mana dan kenapa ada di tempat ini. Sejak kemaluannya ditusuk besi untuk diuji, lalu dikatakan sehat, dia sudah resmi menjadi jugun ianfu. Jadi perempuan pemuas birahi. Dia diberi kamar untuk melayani banyak lelaki. Aku sedih. Dia pasti orang baik. Alisnya sungguh tebal. Masih muda. Mungkin umur dua puluh tahun. Tubuhnya yang putih, sekarang lukanya banyak. Terutama bagian dadanya. Aku juga sedih lihat pahanya yang penuh darah... (Oddang, 2019: 97).

Pada kutipan tersebut dinarasikan akibat yang diderita oleh Hana setelah dipaksa menjad jugun ianfu. Sebelum menjadi jugun ianfu, Hana harus menjalani pemeriksaan organ intim dengan cara ditusuk menggunakan besi. Pemeriksaan tersebut dilakukan untuk mengetahui apakah organ intim Hana memenuhi syarat kesehatan untuk menjadi jugun ianfu. Setelah dipastikan bahwa Hana adalah perempuan yang sehat, perintah untuk melayani tentara-tentara Jepang harus dijalankannya. Akibatnya tubuh Hana mengalami luka-luka karena kekerasan seksual yang dialaminya setiap hari. Bagi tentara Jepang, luka-luka fisik di bagian dada, serta bagian tubuh lainnya bukanlah sebuah hal yang patut diprotes. Alasannya karena Suriani adalah hak milik tentara Jepang sejak dipilih sebagai jugun ianfu.

Penyiksaan fisik yang dialami oleh Hana adalah wujud dari hegemoni kelompok dominan yang tidak memberikan ruang untuk bersuara kepada perempuan pribumi yang ditempatkan sebagai subaltern. Sebagai jugun ianfu tentara Jepang, Suriani atau Hana tidak memiliki posisi yang bermakna untuk berbicara karena tentara Jepang memperlakukannya sebagai kelompok bawah yang dikecualikan. Hana hanya dipandang sebagai subjek diri yang lain, jugun ianfu yang hanya dibutuhkan sebatas tubuh dan pemuas kebutuhan seks.

Dominasi tentara Jepang juga berdampak tekanan psikis pada diri Suriani. Suriani menjadi depresi dan mencoba bunuh diri. Sebelum mencoba bunuh diri, Suriani mencoba mengatasi tekanan psikis dengan cara membayangkan calon suaminya, Hammud, setiap kali dipaksa berhubungan seks. Akan tetapi, Hana gagal memperoleh ketenangan dengan cara tersebut. Akhirnya Hana nekad mencoba gantung diri menggunakan seprai kamar. Usaha tersebut gagal lagi karena dipergoki oleh pelayan rumah pelacuran bernama Kama.

Saya pernah mencoba membayangkan wajah Hammud ketika desah para lelaki brengsek itu terdengar dan embusan nafasnya menyapu wajah saya, tetapi akhirnya saya justru merasa bersalah. Minggu pertama, saya mencoba mengakhiri semuanya dengan mengakhiri hidup saya--tetapi, Kama memergoki dan niat saya jadi urung karena merindukan Suda ketika melihat wajah Kama (Oddang 2019: 98).

Seprai terlilit. Dia tinggal lompat dari kasur, lalu mati, tetapi dia menangis melihatku. Dia turun memelukku. Aku merasa aneh. Selangkanganku mengeras. Aku mengingat kejadian sebelumnya. Sore itu, aku di depan ruangan Hana. Kudengar suara orang marah-marah dari dalam. Lewat celah pintu, aku mengintip. Hana menangis sambil 
ditindih seseorang. Dia sepertinya orang baru. Bukan orang Jepang. Mungkin orang Makassar (Oddang, 2019: 99).

Sesuai pandangan Spivak, subaltern adalah suara yang dibungkam milik orang-orang yang terpinggirkan. Dorongan untuk melakukan perlawanan memang dimiliki oleh seorang subaltern seperti Suriani, namun tidak berhasil karena tidak memiliki superioritas. Tekanan psikis yang dialami Suriani merupakan gambaran dari kegagalan kelompok subaltern memperjuangkan suaranya di bawah tekanan hegemoni penjajah. Usaha Suriani untuk mengakhiri hidupnya sia-sia karena berada pada medan pinggiran sebagai pusat keheningan, pusat tanpa suara. Ditinjau dari pandangan poskolonial, dampak psikis yang dialami Hana merupakan perpanjangan dari kegagalan kelompok subaltern menemukan interaksi yang positif dalam upaya merobohkan dinding subaltern. Kegagalan merobohkan dinding subaltern tersebut terjadi karena status subjek yang dibungkam telah dilekatkan oleh tentara Jepang kepada Hana.

\section{Perlawanan Tokoh Suriani terhadap Dominasi Kekuasaan Tentara Jepang}

Tekanan fisik dan psikis berkepanjangan yang dialami oleh Suriani menyebabkan perempuan itu mulai menunjukkan perlawanan. Resistensi tersebut muncul setelah Hana menyaksikan pengorbanan Kama membunuh tentara Jepang yang memperkosanya. Tindakan Kama secara spontan memicu perlawanan Hana terhadap situasi buruk yang dihadapinya. Hana menyuruh Kama segera melarikan diri ke Sengkang. Dalam upaya perlawanan yang dilakukan Suariani atau Hana tergambarkan penolakan terhadap profesi jugun ianfu, sekaligus menunjukkan sikap toleransinya terhadap sesama pribumi. Akan tetapi, perlawanan Hana gagal karena Kama mati ditembak dan Hana disiksa oleh tentara Jepang. Akhirnya Hana keluar dari rumah pelacuran jugun ianfu dengan kondisi fisik yang sudah luka dan trauma.

"Lari cepat!" hana memaksaku.

"Aku tidak tahu mau ke mana?"

"Kau dari mana?"

Aku sebut nama kampungku. Ternyata Hana tahu. Kami tetangga kampung.

"Ayah dan ibumu?"

"Bapakku mati, tidak sanggup lagi disiksa dan tidak sanggup lagi bekerja paksa. Ibuku sepertimu, tapi mati karena sakit. Karena tidak punya siapa-siapa, aku disuruh kerja dan dijanji setiap hari diberi makan,"

"Pokoknya lari," suara Hana meninggi (Oddang, 2019: 103).

Kini di gerbang kompleks pelacuran, saya bukan siapa-siapa dan tidak memiliki apa-apa. Saya pulang dengan tangan kanan menjinjing tas kulit berwarna coklat yang mulai terkelupas (Oddang, 2019:105).

Teks cerpen tersebut memberikan gambaran resistensi Hana dan akibat yang didapatkannya. Hana tidak berhasil melakukan perlawanan karena dari segi objek historiografi kolonial, maupun sebagai subjek pemberontakan, konstruksi ideologis gender dalam ruang kolonial memperkuat posisi tetap dominan tentara Jepang. Perlawanan Hana tidak mencapai hasil karena dia adalah subjek yang telah diposisikan sebagai perempuan yang dibungkam. Sebagai jugun ianfu dari produk penjajahan Jepang, Suarini hanya diibaratkan sebagai bayanganmemiliki wujud, tetapi tidak memiliki kemampuan untuk melakukan tindakan. Sebagai bayangan, maka seorang subaltern seperti Hana hanya bertindak sesuai perintah dari subjek yang menghasilkan bayangan tersebut.

\section{Subaltern Jugun Ianfu dalam Cerpen Kapotjes dan Batu yang Terapung Karya Faisal Oddang}

Berdasarkan analisis yang telah dikemukakan dapat diketahui jugun ianfu merupakan bagian dari kelompok perempuan yang mengalami subalternisasi oleh tentara Jepang di masa penjajahan Jepang di Makassar. Subalternisasi terhadap para perempuan jugun ianfu tersebut terjadi melalui praktik dominasi kekuasaan oleh tentara Jepang melalui tindakan kekerasan fisik, pelecehan seksual seperti perkosaan, penggantian identitas agar menyerupai identitas perempuan Jepang, serta paksan untuk menghormati lagu kebangsaan dan bendera Jepang. Semua praktik dominasi tersebut menyebabkan dampak luka fisik dan trauma psikis yang berujung percobaan bunuh diri, seperti yang dilakukan oleh Suriani atau Hana. Praktik subalternisasi terhadap perempuan pribumi 
yang dipaksa menjadi jugun ianfu tersebut juga memunculkan perlawanan, tetapi tidak membuahkan hasil, karena sebagai kelompok subaltern, perempuan jugun ianfu tersebut tidak memiliki akses publik, tidak memiliki ruang untuk bersuara dan melakukan protes, serta dianggap sebagai subjek yang tidak memiliki identitas.

Gambaran kelompok perempuan pribumi yang mengalami subaltern tersebut adalah tokoh Suriani atau Hana. Dalam konteks kajian subaltern, Suriani adalah objek eksploitasi yang inferior dan tentara Jepang mewakili subjek yang superior. Melalui tokoh Hana atau Suriani dapat dilihat struktur kekuasaan superior tentara Jepang digunakan sebagai senjata untuk menjajah secara fisik dan mental perempuan pribumi Makassar yang berprofesi jugun ianfu. Sebagai jugun ianfu, dalam pandangan teori poskolonial, khususnya yang dikemukakan oleh (Nelson \& Grossberg, 1989), Suriani adalah orang atau kelompok orang dengan status "yang bertindak", bukan "pihak yang berbicara”. Tentang hal itu Spivak melanjutkan argumennya, dalam budaya kolonialisme, masyarakat terjajah yang berjuangan dengan melakukan perlawanan terhadap bangsa penjajah telah diposisikan sebagai kelompok yang bisu. Kenyataan itu berbeda dengan bangsa penjajah yang diposisikan sebagai kelompok yang memiliki kapasitas untuk berbicara. Perbedaan itu dibungkam oleh perbedaan yang tersimpan dalam kata "sama" serta kesadaran dan hati nurani yang hilang.

Atas dasar pernyataan Spivak tersebut, dalam konteks poskolonial, dialog-dialog dan monolog yang disampaikan Faisal Oddang melalui karakter Suriani atau Hana adalah representasi dari suara-suara perempuan pribumi yang dihilangkan oleh tentara masa penjajahan Jepang di Makassar. Melalui penokohan Suriani, Faisal Oddang juga mengemukakan wacana tandingan atas wacana penjajahan Jepang — wacana yang menegaskan bahwa perempuan pribumi Indonesia adalah sosok yang tidak pantas untuk ditindas. Atas ketidakpantasan tersebut, Faisal Oddang merepresentasikan perlawanan pribumi Indonesia terhadap praktik jugun ianfu melalui tindakan Suriani yang mencoba bunuh diri serta melarikan diri dari tempat penampungan jugun ianfu. Perlawanan tersebut juga tergambar dari pergolakan batin yang dialami Suriani saat ia dipaksa mengikuti upacara penghormatan kepada bendera dan lagu kebangsaan Jepang yang diperdengarkan di tengah lapangan. Perlawanan itu berlanjut dengan munculnya rasa benci Suraini terhadap tubuhnya sendiri, karena tubuhnya dipandang sebagai objek yang meninggalkan jejak sejarah penjajahan.

Dalam wacana bangsa penjajah, tindakan tentara Jepang terhadap Suriani yang berprofesi sebagai jugun ianfujuga mencerminkan fakta-fakta masa lalu—bagaimana Jepang menunjukkan sikap perlawanan atau antibarat dengan memaksakan pola hegemoni kultur berorientasi Jepang kepada perempuan Indonesia. Dikaitkan dengan politik penjajahan Jepang semasa perang Asia Pasifik, ribuan perempuan Asia dipaksa menjadi jugun ianfu dengan dalih mengajaknya berpartisipasi dalam memenangkan perang. Selama politik hegemoni tersebut dijalankan, Jepang memperkuat posisi superiornya dengan trik politik antikolonial. Caranya adalah menghapus semua hal yang berbau Barat di negara jajahannya dan menukar identitas perempuan-perempuan yang dipilih sebagai jugun ianfu menjadi mirip dengan perempuan Jepang.

Peristiwa penggantian nama Suriani menjadi Hana yang dialami oleh Suriani adalah cerminan politik Jepang untuk memperkuat hegemoni budaya Jepang di negara jajahannya, sekaligus sebagai tindakan menghapus identitas Barat dari identitas perempuan pribumi Indonesia. Dalam sejarah penjajahan Jepang di berbagai negara Asia Pasifik dan Asia Tenggara, Jepang memang memberlakukan hegemoni dengan cara menanamkan elemen kesadaran pro Jepang. Elemen yang sama yang hendak didistribusikan kepada perempuan jugun ianfu adalah kesadaran politik Jepang yang menolak kultur Barat. Untuk mencapai hal itu Jepang melekatkan atribut penjajahan ideologi, politik kekuasaan superior, dan hegemoni kepada jugun ianfu di berbagai negara jajahan. Terkait dengan tindakan penggantian nama tersebut, Spivak (Spivak, I988) menyatakan kelompok masyarakat tertindas, contohnya petani miskin, tidak akan pernah mampu untuk membangun kekuatan kelasnya sendiri. Sebagai kelompok miskin dan tertindas, mereka dipandang sebagai kolektif yang tidak memiliki nama bangsa, tidak memiliki sejarah muasal diri, serta tidak memiliki sejarah tradisi. Sebagai subjek yang tidak memiliki identitas tersebut, maka sejarah dirinya dapat dikonstruksi atau dibentuk kembali oleh kolonialisme untuk kepentingan kapitalis yang berorientasi kepada pola-pola kultur maskulin. Kaitannya dengan peristiwa penggantian nama tokoh Suriani menjadi Hana, hal itu dilakukan oleh tentara Jepang, tidak lain dan tidak bukan merupakan upaya merekonstruksi identitas kelompok masyarakat jajahannya 
agar dapat diperlakukan sesuai politik identitas yang dibangun di atas pola kekuatan maskulinitas kemiliteran.

Selain penggantian nama, pembentukan kesadaran perempuan subaltern agar pro penjajah Jepang digambarkan dalam peristiwa upacara penghormatan terhadap lagu kebangsaan Jepang dan harus membungkuk beberapa saat ke arah matahari terbit. Cara tersebut diyakini Jepang sebagai cara pembentukan kesadaran jugun ianfu untuk patuh dan mengakui kekuasaan Jepang. Dalam peristiwa tersebut Suriani dan jugun ianfu lainnya diposisikan sebagai subjek-subjek yang tidak memiliki suara. Dalam konteks pemahaman subjek subaltern yang dikemukakan oleh Spivak (Nelson \& Grossberg, 1989), tindakan pemaksaan yang dialami oleh Suriani agar menghormati bendera dan lagu kebangsaan Jepang merupakan cerminan dari struktur eksploitasi yang pada dasarnya adalah bagian dari kepentingan kekuasaan kelompok atau kelas penguasa. Dalam lingkup yang lebih luas, menurut Spivak, hal itu merupakan upaya eksploitasi kapitalis yang diwujudkan dengan berbagai bentuk dominasi, satu di antaranya adalah dengan politik kepentingan identitas bangsa penjajah.

Peristiwa lain yang dialami Suriani yang memperkuat statusnya sebagai subaltern adalah keharusan menjalani tradisi sebelum menjadi jugun ianfu. Tradisi itu adalah pemeriksaan alat kelamin Suriani oleh dokter dengan cara menusuk menggunakan besi cocor bebek. Tujuannya adalah untuk memastikan bahwa Suriani tidak memiliki riwayat penyakit kelamin yang dipantangkan bagi seorang calon jugun ianfu. Praktik tersebut termasuk pelanggaran hak azazi manusia dan pelecehan terhadap kehormatan perempuan pribumi, karena alat kelamin sangat bersifat privasi dan intim yang menutup ruang adanya perlakuan secara kasar. Akan tetapi, Suriani tidak dapat melawan tindakan tersebut karena statusnya adalah bagian dari kelompok masyarakat yang berada dalam kekuasaan penjajah. Dalam kerangka pemikiran Spivak (Spivak, 1988) budaya maskulin patriarki menjadi bagian penting dalam politik identitas penjajah terhadap subjek subaltern. Kaum perempuan dimasukkan ke dalam daftar kaum tertindas yang dapat dieksploitasi untuk berbagai kepentingan politik penjajah yang sarat dengan ideologi maskulin patriarki. Penindasan tersebut dilakukan untuk membendung kemungkinan suara-suara dari subjek perempuan dalam melawan sistem kolonialisme yang monolitik. Penindasan itu menurut Spivak, dimulai dari pengucilan dalam formasi keluarga, khususnya dalam formasi keluarga dari kelas tertentu. Kasus pemeriksaan alat kelamin Suriani secara paksa menggunakan besi cocor bebek merupakan representasi dari kekuasaan maskulin patriarki yang mewakili hegemoni kekuasaan penjajahan Jepang terhadap subjek subaltern jugun ianfu. Penusukan alat kelamin dengan besi cocor bebek tanpa seizin pemiliknya juga dapat dipandang sebagai gambaran bahwa kelompok penjajah memiliki kekuasaan yang tidak terbatas untuk memperlakukan bangsa jajahan sesuai kepentingan penjajahan. Masyarakat dari bangsa terjajah tidak memiliki privasi apapun karena tidak memiliki kekuasaan dan suara untuk melawan, seperti halnya disimbolkan dengan daerah intim bagi subaltern jugun ianfu yang tidak dapat dipertahankan sebagai bagian paling pribadi dari perempuan bangsa terjajah.

Koheren dengan berbagai eksploitasi fisik dan seksual yang dialami oleh tokoh Suriani tersebut, Spivak (Nelson \& Grossberg, 1989) juga berpandangan perempuan subaltern tidak memiliki identitas, jika dibandingkan dengan laki-laki. Pandangan tersebut mengakibatkan perempuan-perempuan subaltern mendapatkan perlakuan ketidakadilan gender. Gender maskulin yang diwakili oleh penjajah melakukan penindasan dan kekerasan seksual terhadap gender feminin. Gender feminin diposisikan sebagai bayangan, tidak memiliki jati diri, berbeda dengan gender maskulin yang diposisikan sebagai pemilik kekuatan dan kekuasaan yang dominan.

Ditinjau kembali dari upaya pembentukan kesadaran politik proJepang, tradisi yang harus dijalani oleh Suriani memang telah diterapkan kekaisaran Jepang di berbagai negara jajahannya. Dilihat dari historisnya, sampai pada tahun 1943, Jepang pernah merekrut sekitar 200.000 perempuan dari berbagai negara jajahannya. Selama perang Asia Pasifik, 70.00 sampai 80.000 orang perempuan tersebut telah dijadikan jugun ianfu. Kekaisaran Jepang memilih perempuan-perempuan muda yang telah dipastikan sehat dan tidak memiliki riwayat penyakit kelamin. Tujuan Jepang memilih perempuan pribumi yang sehat adalah untuk menghindari serangan penyakit menular seksual terhadap para tentaranya. Kekaisaran Jepang sangat peduli dengan hal itu, karena keberadaan jugun ianfu adalah sebagai hiburan biologis agar tentaranya terhindar dari tekanan kehidupan militer yang hierarkis.

Iswadi Bahardur, Subaltern jugun ianfu dalam cerpen Kapotjes dan Batı yang Terapungkarya Faisal Oddang: Tinjauan poskolonial Gayatri Spivak 
Bukti lain yang menguatkan stigma jugun ianfu sebagai bagian dari kelompok yang ditindas gender maskulin adalah peristiwa dalam cerpen Kapotjes dan Batu yang Terapung yang menggambarkan fasilitas yang diberikan tentara Jepang kepada Suriani di tempat penampungan jugun ianfu. Kamarnya hanya berukuran 2x3 meter, ranjang, meja, pencuci alat kelamin, kapotjes (alat pelindung, sejenis kondom di zaman Jepang), cerek berisi air, serta dua buah gelas. Fasilitas tersebut menggambarkan bahwa Hana adalah orang yang tidak dipandang sebagai manusia yang memiliki harga diri atau hak hidup yang layak. Fasilitas tersebut diberikan kepadanya juga sebatas kepentingan untuk melayani kebutuhan seksual setiap tentara Jepang yang membayarnya 3-5 yen. Kondisi tersebut merupakan cerminan bahwa bagi penjajah Jepang, jugun ianfu dipandang sebagai kelompok perempuan marginal yang tidak memiliki identitas sosial, tidak ditempatkan pada strata sosial yang layak, dan tidak memiliki ruang hidup dengan standar normatif.

Kasus yang dialami Suraini selama menjadi jugun ianfu memiliki koherensi dengan pandangan Spivak (Nelson \& Grossberg, 1989) tentang bagaimana cara bangsa yang menjadi penjajah memperlakukan masyarakat di negara jajahannya. Dalam argumentasinya, Spivak menyatakan bangsa penjajah yang dominan berspekulasi bahwa dalam relasi sosial dengan masyarakat di negara jajahan, reproduksi ideologis adalah milik penguasa. Oleh karena itu, masyarakat terjajah yang dipekerjakan (dalam cerpen karya Faisal Oddang diwakili oleh perempuan Makassar yang dijadikan jugun ianfu) reproduksi tenaga kerja tidak hanya membutuhkan keterampilannya, tetapi pada saat yang sama juga akan ada eksploitasi dan penindasan. Dalam praktik tersebut, masyarakat terjajah, seperti halnya Suriani, harus menerima resiko, dominasi kelas berada di tangan penjajah. Atas dasar argumentasi Spivak tersebut, maka penindasan dan eksploitasi seksual yang dialami oleh Suriani merupakan bentuk konsekuensi yang harus diterimanya sebagai perempuan pribumi yang dipekerjakan sebagai jugun ianfu tentara Jepang

Hasil kajian permasalahan subaltern jugun ianfu dalam cerpen Kapotjes dan Batu yang Terapung, juga dapat dibandingkan dengan hasil penelitian lainnya. Perbandingan temuan masalah yang sama, diantaranya dapat dilihat dari hasil Bahardur (Bahardur, 2017). Dari hasil pembacaan dapat ditarik benang merah kaitan temuan kedua hasil penelitian tersebut dengan kajian cerpen Kapotjes dan Batu yang Terapung. Benang merah tersebut adalah perempuan-perempuan pribumi di masa kolonial mengalami perlakuan sebagai subaltern dengan berbagai pola. Penjajah Belanda memposisikan perempuan pribumi sebagai anggota kelas bawah, tidak memiliki hak untuk menjadi dirinya sendiri, dan tidak memiliki suara untuk melawan. Penjajahan Jepang juga memperlakukan perempuan pribumi sebagai subaltern dengan tujuan untuk keuntungan politik penjajahan Jepang. Hal yang membedakan hanya pada konteks suku bangsa dan budaya yang melatarinya. Dari ketiga hasil penelitian tersebut memperlihatkan persamaan realitas imajinatif perempuan-perempuan pribumi yang berasal dari etnis Jawa, etnis Sumatera, dan etnis Bugis--menjalami subalternisasi dengan berbagai pola. Perempuan-perempuan etnis Jawa, misalnya, diperlakukan sebagai subaltern dalam ruang domestik. Diantaranya menjadi perempuan simpanan dan pelayan kebutuhan rumah tangga bagi lelaki kolonial, seperti ditemukan Saputra dalam penelitian terhadap novelnovel Indonesia berlatar daerah Jawa. Perlakuan yang sama juga diterima perempuan pribumi dari etnis Bugis, seperti Suriani dalam cerpen karya Faisal Oddang. Suriani dipaksa menjadi jugun ianfu, perempuan penghibur dan mendapat berbagai tindakan kekerasan seksual di masa penjajahan Jepang. Dengan temuan tersebut dapat diketahui, penjajahan Belanda juga telah meninggalkan dampak pada penduduk pribumi Indonesia. Dampak itu adalah terbentuknya mental penjajah dalam diri laki-laki di Indonesia, seperti temuan penelitian Bahardur tersebut.

Temuan penelitian masalah subaltern jugun ianfu dalam cerpen karya Faisal Oddang juga dapat diperbandingkan dengan hasil penelitian (Kholifatu \& Tjahjono, 2020). Penelitian tersebut mengkaji permasalahan subaltern dalam masyarakat era kerajaan Singosari. Kelompok dominan dan superior adalah pemilik kasta tertinggi di kerajaan, yaitu kasta Brahmana dan kasta Ksatria yang diwakili oleh Tunggul Ametung, sedangkan kelompok subaltern adalah rakyat jelata yang diwakili oleh Ken Arok. Perlawanan kelompok subaltern yang dilakukan oleh Ken Arok mengakibatkan pertumpahan darah. Temuan Kholifatu tersebut menunjukkan fakta sejarah bahwa ternyata subaltern tidak hanya pernah muncul di zaman kolonial di Indonesia. Jauh sebelum masa penjajahan Belanda dan juga Jepang, masyarakat kelas bawah telah mengalami penindasan sejak zaman kerajaan-kerajaan di nusantara. Motif penindasan yang dialami oleh masyarakat kelas bawah tersebut lebih didasarkan pada perbedaan kasta. Hasil penelitian tersebut juga memperlihatkan bahwa kultur masyarakat 
patriarki, seperti dalam masyarakat Jawa menjadi motif yang sangat kuat dalam terciptanya kelompok masyarakat subaltern.

Dari perbandingan tersebut dapat diketahui bahwa masa penjajahan Belanda dan juga Jepang di Indonesia telah terjadi praktik subaltern hampir di dalam semua etnis dan kelompok masyarakat. Penyebabnya adalah hegemoni kekuasaan kolonial Belanda dan Jepang, serta diperkuat oleh budaya patriarki. Praktik subaltern tersebut berlanjut sampai ke era pascakolonial, mewujud dalam praktik kolonial model baru, misalnya penindasan hak-hak perempuan pribumi di ruang publik dan privasi rumah tangga. Perbedaan konteks praktik subaltern tersebut hanya dari segi latar waktu, latar budaya, serta pola-pola hegemoni oleh gender maskulin. Pada masa kolonial Belanda, subaltern dari etnis Jawa diperlakukan sebagai budak seks dan pelayan rumah tangga, namun diperhalus bahasanya menjadi gundik atau istri simpanan. Faktanya sebagai perempuan gundik, para perempuan Jawa tetap saja tidak memiliki hak suara, hanya dimanfaatkan sebagai objek tanpa status yang diakui secara sah.

Dalam konteks masyarakat global, permasalahan subaltern juga dialami oleh masyarakat yang diposisikan sebagai subjek bawah. Ezzeldin (2017) dalam hasil penelitiannya berkenaan dengan subaltern dalam novel-novel berlatar masyarakat era Victoria di Britania, yaitu dari novel Jane Eyre karya Charlotte Bronte, Wuthering Heights karya Emily Bronte, dan The Sign of Four karya Arthur Conan Doyle. Ezzeldin menemukan narasi subaltern Victorian dalam ketiga novel tersebut terbentuk dari situasi kehidupan masyarakat kelas bawah di Inggris. Kelompok subaltern dalam masyarakat Inggris era Victoria tersebut terekspos karena adanya tindak kejahatan, kebencian, usaha balas dendam, pembunuhan, dan penindasan yang dilatari oleh perbedaan ras dan warna kulit.

Hasil dari semua penelitian tersebut memberikan penguatan bahwa subalternisasi, seperti yang dialami oleh jugun ianfu zaman Jepang dalam cerpen Kapotjes dan Batu yang Terapung adalah masalah global. Sebagai masalah global, subjek subaltern dapat ditemukan dalam berbagai kelompok suku, bangsa, bahkan periodesasi tahun tertentu. Di Indonesia, misalnya, kasus-kasus subaltern, selain yang dialami oleh tokoh Suriani yang berasal dari masyarakat pribumi Makassar era penjajahan Jepang, juga ditemukan dalam masyarakat etnis Jawa era penjajahan kolonial dan era kerajaan Singosari. Dalam era pascakolonial, kasus-kasus subaltern ternyata masih berlanjut dalam bentuk baru. Subaltern dalam bentuk neokolonialisme tersebut diantaranya penindasan hak-hak perempuan di ruang privasi dan publik. Sementara dalam konteks global, subaltern dapat terjadi bukan hanya karena kolonialisme, melainkan juga karena perbedaan ras dan warna kulit.

\section{SIMPULAN}

Berdasarkan analisis dan pembahasan data penelitian dapat disimpulkan, praktik subaltern jugun ianfu yang digambarkan dalam cerpen Kapotjes dan Batu yang Terapung karya Faisal Oddang terjadi karena adanya hegemoni kekuasaan tentara Jepang dalam relasi gender yang hirarkis antara kelompok gender maskulin yang superior, dan gender feminin sebagai kelompok yang inferior. Dalam konteks permasalahan subaltern, praktik jugun ianfu terjadi dapat dipandang dari tiga hal, yaitu pengaruh dominasi superior terhadap inferior, dampak dominasi terhadap kelompok inferior, serta upaya kelompok inferior untuk melakukan perlawanan. Dapat dilihat bahwa dominasi kelompok superior terhadap jugun ianfu berdampak pada kerusakan fisik, seperti luka-luka dan pendarahan, serta tekanan psikis yang berujung pada tindakan percobaan bunuh diri. Dampak demikian disebabkan oleh dominasi kekuasaan tentara Jepang terhadap perempuan pribumi dalam bentuk kekerasan seksual, penukaran nama asli dengan nama khas perempuan Jepang, dikurung dalam kamar berukuran 2x3 meter tanpa busana, dan tanpa makanan, diharuskan mengikuti upacara dan lagu kebangsaan Jepang, serta diharuskan menundukkan badan sebagai penghormatan terhadap bendera kebangsaan Jepang. Dalam konteks kajian subaltern Gayatri Spivak, perlakuan yang diterima oleh subaltern jugun ianfu dari Indonesia adalah gambaran dari kelompok bawah yang tidak memiliki identitas karena suaranya telah dihilangkan oleh kelompok dominan yang berkuasa. Dalam konteks kajian tentang sejarah Indonesia dan keterkaitannya dengan teks-teks sastra poskolonial, kajian terhadap masalah subaltern tersebut berimplikasi terhadap telaah karya sastra yang bertemakan masalah perempuan subaltern dalam teks-teks pascakolonial untuk mengenalkan kembali sejarah perjuangan kemerdekaan Indonesia, baik kepada pembaca umum, siswa, maupun mahasiswa di perguruan tinggi. Selain itu, kajian tentang subaltern jugun ianfu dalam cerpen Kapotjes dan Batu yang Terapung karya Faisal Oddang juga dapat

Iswadi Bahardur, Subaltern jugun ianfu dalam cerpen Kapotjes dan Batı yang Terapungkarya Faisal Oddang: Tinjauan poskolonial Gayatri Spivak 
berimplikasi terhadap kesadaran masyarakat pembaca sastra Indonesia tentang pentingnya sikap nasionalis dalam rangka menghapus jejak mental penjajah dari masyarakat pribumi.

\section{UCAPAN TERIMA KASIH}

Terima kasih kepada semua rekan sejawat, penulis buku yang menjadi sumber data penelitian, serta semua pihak yang terlibat membantu proses penelitian dari awal hingga selesai.

\section{DAFTAR PUSTAKA}

Ardianto, Ardik. (2020). Gaya kepenulisan Pramoedya: Stilistika atas roman Bumi Manusia Ardik. KEMBARA: Jurnal Keilmuan Bahasa, Sastra, dan Pengajarannya (e-Journal), 6(I), 39-48. doi: https://doi.org/I0.22219/kembara.v6iI.II688

Ashcroft, B., Griffiths, G., \& Tiffin, H. (2013). Post-colonial studies: The key concepts. In Choice Reviews Online (Second Edi, Vol. 39). London: Routledge.

Rahma, A. D., Suswandari, S., \& Naredi, H. (2020). Jugun ianfu: Kekerasan seksual terhadap perempuan pada masa pendudukan Jepang di Jawa Barat Tahun I942-I945. Chronologia, I(3), 36-49. doi: https://doi.org/http://dx.doi.org/I0.29405/xxxxx

Bahardur, I. (2017). Pribumi subaltern dalam novel-novel Indonesia pascakolonial. Gramatika STKIP PGRI Sumatera Barat, 4(I), 89-I00. doi: https://doi.org/I0.22202/jg.2017.v3iI.1876

Bharati, S., \& Adkoli, N. (20I8). Shifting paradigms in subaltern literature: Women as subaltern. Shanlax International Journal of English, 6(SI), I00-I02. doi: https://doi.org/https://doi.org/I0.528I/ zenodo.I42II6I

Brennan, L., \& Guha, R. (1982). Subaltern studies I. Writings on South Asian History and Society. Oxford University Press. New Delhi: Sage Publications.

Chandra, U. (20I5). Rethinking subaltern resistance. Journal of Contemporary Asia, 45(4), 563-573. doi: https:/ /doi.org/IO.I080/00472336.20I5.I0484I5

Chaturvedi, V. (Ed.). (2000). Mapping subaltern studies and the postcolonial. In edited by Vinayak Chaturvedi (Ed.), Verso (First Edit). London: Verso.

Creswell, J. W., \& Creswell, J. D. (2017). Research design: Qualitative, quantitative, and mixed methods approaches. Amerika: Sage publications.

De Jong, S., \& Mascat, J. M. (2016). Relocating subalternity: scattered speculations on the conundrum of a concept. Cultural Studies, 30(5), 717-729. doi: https://doi.org/I0.I080/09502386.2016.II68109

Dharmaraj, P. M. (20I4). Indian writing in English: Subaltern literary concept-oppression of untouchables in rohinton mistry's a fine balance. International Journal on English Language and Literature, 2(I), 36-38.

El, H. L. (2012). Retracing the concept of the subaltern from Gramsci to Spivak: Historical developments and new applications. African Journal of History and Culture, 4(I), 4-8. doi: https://doi.org/I0.5897/ajhcI I.020

Ezzeldin. (2017). (Un) Representations of the subaltern in three victorian novels. International Journla of Humanities and Cultural Studies, 3(4), I04-I I5.

Farida, N., \& Andalas, E. F. (2019). Representasi kesenjangan sosial-ekonomi masyarakat pesisir dengan perkotaan dalam Novel Gadis Pantai karya Pramodya Ananta Toer. KEMBARA: Jurnal Keilmuan Bahasa, Sastra, dan Pengajarannya (e-Journal), 5(I), 74-86. doi: https:// doi.org/I0.22219/kembara.vo15.no I.74-90

Geographic, M. N. (2020). Nestapa nona Jawa: Perempuan korban perang (pp. 19-40). pp. 19-40. Jakarta.

Guha, R., \& Spivak, G. C. (2002). Subaltern studies-modernità e (post)colonialismo. London: Hamilton Books.

Hata, I. (20I8). Comfort women and sex in the battle zone. London: Hamilton Books. 
Hein, P. (2016). Unresolved comfort women issue: how pragmatism precludes reconciliation. The Korean Journal of International Studies, I4(3), 447. doi: https://doi.org/IO.I473I/kjis.2016.I2.I4.3.447

Ilma, A. A. (2016). Representasi penindasan ganda dalam Novel Mirah dari Banda: Perspektif feminisme poskolonial. Jurnal Poetika, 4(I), I-I3. doi: https://doi.org/I0.22I46/poetika.I33IO

Kholifatu, A., \& Tjahjono, T. (2020). Subaltern dalam Novel Arok Dedes karya Pramoedya Ananta Toer: Kajian poskolonial Gayatri Spivak. Stilistika: Jurnal Pendidikan Bahasa dan Sastra, I3(I), I20_ I26. doi: https://doi.org/I0.3065I/st.vI3iI

Krippendorff, K. (2018). Content analysis: An introduction to its methodology. London: SAGE Publications, Inc.

Kristi. (2016). Perbedaan respon Indonesia dan Korea Ianfu terhadap Jepang. Jurnal Analisis Hubungan Internasional, 5(2), 323-332.

Kumar, V. (2016). The concept of subaltern in Munshi Premchand's Sevasadan. International Journal of Advanced Research and Development ISSN:, I(I), 58-6I.

Mashaqi, S. A. A. (2017). A postcolonial approach to the problem of subalternity in Toni Morrison's God help the child. International Journal of Applied Linguistics and English Literature, 7(I), I77-I83. doi: https://doi.org/I0.7575/aiac.ijalel.v.7n.Ip.I77

Miles, M. B., \& Huberman, A. M. (1994). Qualitative data analysis: An expanded sourcebook. In Sage Publication (Second Edi). London: Sage Publications.

McGregor, K. (2016). Emotions and activism for former so-called "comfort women" of the Japanese occupation of the Netherlands East Indies. Women's Studies International Forum, 54, 67-78. doi: https://doi.org/I0.I0I6/j.wsif.20I5.II.002

Mussi, D. X. H. (2017). Antonio Gramsci e a crítica da cultura: intelectuais, política e classes subalternas. Revista Katálysis, 20 I), 93-I02. doi: https://doi.org/I0.I590/I4I4-49802017.00100007

Nelson, C., \& Grossberg, L. (Eds.). (I988). Marxism and the interpretation of culture. London: University of Illinois Press.

Nelson, C., \& Grossberg, L. (1989). Marxism and the interpretation of culture. In C. N. and L. Grossberg (Ed.), South Atlantic Review (Vol. 54). doi: https://doi.org/I0.2307/3200554

Ningrum, R. K., Waluyo, H. J., \& Winarni, R. (2017). Representation of Japanese post-colonial experience in the Year of I942-1945 based on Pramoedya Ananta Toer's Novel "Perburuan". Humanus: Jurnal Ilmiah Ilmu-ilmu Humaniora, I6(I), I05-II7. doi: https://doi.org/I0.24036/jh.vI6iI.7943

Nozaki, Y. (2005). The "comfort women" controversy: History and testimony. Japan Focus, 336(7), II7.

Oddang, F. (2019). Sawerigading datang dari laut. Yogyakarta: DIVA Press.

Pramana, Y., Rahayu, S. S., Mariati, S., \& Indonesia, J. S. (2013). Dimensi pernyaian dan jugun ianfu novel Mirah dari Banda karya Hanna Rambe: Kajian Feminisme Eksistensialis. Publika Budaya, $I(\mathrm{I}), \mathrm{I}-\mathrm{I} 2$.

Saldana, J. (20II). Fundamentals of qualitative research: Understanding qualitative research. London: Oxford University Press,.

Santosa, B. T., \& Ocktarani, Y. M. (2020). Dekonstruksi narasi subaltern Siti Walidah dalam naskah drama Nyai Ahmad Dahlan (2017) karya Dyah Kalsitorini: Pendekatan subaltern Gayatri Spivak. Atavisme, 23(I), 33-43. doih: ttps://doi.org/I0.24257/atavisme.v23iI.591.33-43

Savitri, D. (20I0). Terhadap jugun-ianfu sebagai hegemoni kebudayaan di Indonesia Periode I942-I 945. Jurnal Kriminologi Indonesia, 6(Iii), 284-295.

Saxena, V. (2019). "The returning echoes of our memory" networks of memory and postcolonial trauma in Tan Twan Eng's The Gift of Rain. Kritika Kultura, 34(May), I80-197. doi: https://doi.org/doi.org/I0.13185/KK2020.03309

Sengupta, P. (2017). The subaltern voice in Kylas Chunder Dutt's a journal of forty-eight hours of the

Iswadi Bahardur, Subaltern jugun ianfu dalam cerpen Kapotjes dan Batı yang Terapungkarya Faisal Oddang: Tinjauan poskolonial Gayatri Spivak 
year 1945. Rupkatha Joumal on Interdisciplinary Studies in Humanities, 9(2), 220-232. doi: https://doi.org/10.21659/rupkatha.v9n2.23

Setiawan, A., \& Musaffak, M. (2019). Eksistensi mistisisme dalam novel Amba karya Laksmi Pamuntjak KEMBARA: Jurnal Keilmuan Bahasa, Sastra, dan Pengajarannya (e-Journal), 5(2), I46-I56. doi: https://doi.org/I0.22219/kembara.v5i2.9672

Setiawan, R. (2018). Subaltern, politik etis, dan hegemoni dalam perspektif Spivak. Jurnal POETIKA, 6(I), I2. doi: https://doi.org/I0.22I46/poetika.35013

Spivak, G. C., Landry, D., \& MacLean, G. M. (1996). The Spivak reader: Selected works of Gayatri Chakravorty Spivak. In New York. Retrieved from http://www.amazon.com/Spivak-ReaderSelected-Gayati-Chakravorty/dp/04I59I00I3

Sumra, S., \& Taseer, M. (2018). Subalternity in the pearl that broke its shell: An alternative feminist analysis. International Journal of English Language \& Translation Studies, 06(04), I60-173. Retrieved from: www.eltsjournal.org

Susanto, D., \& Wati, R. (2019). Wacana romantisme dalam sejarah sastra indonesia periode kolonial belanda (1900-1942). KEMBARA: Jurnal Keilmuan Bahasa, Sastra, dan Pengajarannya (ejoournal), 5(I), 40. doi: https:// doi.org/I0.22219/kembara.vol5.noI.40-52

Tami, R., Faruk, F., \& Adi, I. R. (2017). Hegemonic culture and subaltern: A compromised veil in Indonesian Islamic popular novel. Lingua Cultura, II(I), I3. doi: https://doi.org/I0.2I512/lc.vIIiI.I729

Williams, R. P., Williams, P., \& Chrisman, L. (Eds.). (20I I). Colonial Discourse And Post-Colonial Theory A Reader. In Can The Subaltern Speak?(pp. 27I-279).

Young, R. J. C. (2003). Postcolonialism: A very short introduction. In Oxford (First Edit). New York.

Yousef, T., \& Al-Rubwfiq, A. (2016). The subaltern in some selected poems by Mahmoud Darwish. Journal of Cultural and Religious Studies, 4(5), 286-299. doi: https://doi.org/I0.17265/2328-2177/2016.05.002

Yu, T. (20I3). Reincarnation of the Pinay subaltern in foreign cinema. Kritika Kultura, 22(2I-22), 584-6I0. doi: https://doi.org/I0.13I85/kk2013.02I35

Tanaka, Tanaka. (2002). Japan's comfort women: Sexual slavery and prostitution during world war ii and the US Occupation. In Routledge. 